\title{
Improving the Health Quality of Fried Falafel (Middle Eastern Food) by Using Transglutaminase and/or Pectin Coating
}

\author{
Asmaa Al-Asmar ${ }^{1,2}$, Concetta Valeria L. Giosafatto ${ }^{1}$, Lucia Panzella ${ }^{1}$ and Loredana Mariniello ${ }^{1, *}$ \\ 1 Department of Chemical Sciences, University of Naples “Federico II", 80126 Naples, Italy; \\ asmaa.alasmar@unina.it (A.A.); giosafat@unina.it (C.V.L.G.); panzella@unina.it (L.P.) \\ 2 Analysis, Poison control and Calibration Center, An-Najah National University, P.O. Box 7 Nablus, \\ Palestine \\ * Correspondence: loredana.mariniello@unina.it; Tel.: +39-081-2539-470
}

Received: 15 February 2019; Accepted: 18 February 2019; Published: 3 March 2019

\begin{abstract}
In this study we investigated the effect of transglutaminase (TGase) addition to the falafel dough followed or not by dipping into pectin (PEC 1\%) coating solution. Acrylamide (ACR), oil and water content of the fried falafel balls treated or not by TGase (5 or $20 \mathrm{U} / \mathrm{g}$ of chickpea proteins) and coated or not with PEC-containing film forming solutions were evaluated. Texture profile analyses and in vitro gastric digestion experiments were also carried out. We observed that the ACR content was reduced, compared to control sample, by $10.8 \%$ and $34.4 \%$ in the samples set up by adding 5 and $20 \mathrm{U}$ TGase/g, respectively. In PEC-coated samples, ACR reduction was about $59 \%, 65.3 \%$ and $84.5 \%$, in falafel balls prepared either without TGase or containing 5 or $20 \mathrm{U}$ of the enzyme. However, TGase treatment does not affect oil content, while the PEC coating reduces the oil uptake by $23.5 \%$. No difference was observed between the control sample and the one dipped in PEC regarding their texture properties while these properties were influenced in samples set up in the presence of the enzyme. Finally digestion studies demonstrated that the falafels prepared in the presence of TGase are digested in the gastric environment.
\end{abstract}

Keywords: Falafel; acrylamide; transglutaminase; pectin; oil uptake

\section{Introduction}

Falafel is traditionally fast and street food in Middle Eastern, also known as "ta 'amiyya" in Egypt and Sudan, and it is a deep fried ball made of spiced fava beans and/or chickpeas [1,2]. Nowadays several countries like Palestine, Jordan, Lebanon, Syria and other Middle Eastern counters use chickpeas to prepare this most popular fast food that is eaten for breakfast and also for dinner. The chickpea was used as a food popular in the East since 4000 BC [3]. Falafel dough is made of a mixture of soaked ground chickpeas, parsley, onions, spices and leavened by sodium bicarbonate. The dough is shaped as balls just before deep-frying in vegetable oil until they become crusty and brown [2,4]. According to United States Department of Agriculture USDA [5], the homemade falafel contains $13.3 \%$ proteins, $17.8 \%$ total fat, $31.8 \%$ carbohydrate and it is a rich source of different minerals like calcium, magnesium, phosphorus, potassium, sodium and also vitamins such as folate, vitamin C, vitamin A.

In 2002 Swedish researcher discovered that exposure of starch containing foods to temperatures above $120^{\circ} \mathrm{C}$ in a low moisture environment provokes formation of acrylamide (ACR, 
$\left.\mathrm{H}_{2} \mathrm{C}=\mathrm{CH}-\mathrm{CO}-\mathrm{NH}_{2}\right)$, that is highly soluble in water [6,7]. According to European Food Safety Authority (EFSA), ACR is produced in numerous baked and fried foods, including French fries, potato crisps, breads, biscuits, and coffee (roasted beans). EFSA scientists conclude that ACR is a health concern [8]. Moreover, the pathway of ACR formation probably involves Strecker degradation of amino acids, especially asparagine in the presence of dicarbonyl products from the Maillard reaction. Al-Dmoor et al. [4], indicated that ACR in Jordanian fried falafel (cooked for 6-8 min at $160-180{ }^{\circ} \mathrm{C}$ ) have very high values ranging from 2700 to $4200 \mu \mathrm{g} \mathrm{kg}^{-1}$, moreover, the same study demonstrated that the excessive use of frying oil in food preparation caused significant increases $(\sim 33 \%)$ in ACR content. Very little work has been done to decrease oil absorption in fried falafel balls and the only indications come from Abu-Alruz. [2], which assessed that increasing falafel ball size provokes a reduction of oil uptake together with a decrease of frying time.

Transglutaminases (TGase, EC 2.3.2.13) are a widely distributed groups of enzymes that crosslink protein through an acyl-transfer reaction resulting in a $\varepsilon$ - $(\gamma$-glutamyl) lysine isopeptide bond. Recently, using TGase to improve the physiochemical properties of different food products and also edible films and coatings are rise up due to the ability of TGase to improve the crosslink network inside the food matrixes $[9,10]$. Due to the enzymatic cross-linking of milk proteins by TGase, yoghurt viscosity and yield stress were increased [11]. Moreover, TGase was successfully founded that is substrate for many proteins such as egg proteins [12], fish proteins [13], soy proteins [14,15], bitter vetch proteins [16], grass pea proteins [17].

Pectins (PEC) are plant cell wall structural polysaccharides composed mainly of galacturonic acid units with variations in composition, structure and molecular weight [18]. In general, PEC (E440) are used as food additive, known as thicker or stabiliser used to prepare different food products like jelly, jam, marmalades and other products, due to the their gelling properties [19]. PEC are also used in pharmaceuticals and cosmetics industry due to all these properties. Moreover, PEC applications are devoted to increase since these biopolymers have great potential and possibilities for future developments [20]. Coatings are one of the most important food preservation methods that are applied to protect highly perishable foods by creating a thin layer of edible materials onto surfaces of the products. For example, Yossef [21], find out that PEC coated strawberry fruits retained physico-chemical properties and visual quality significantly in comparison to the ones coated by soy proteins, gluten, or starch.

Healthy food is becoming the most interesting objective for several industries and for a large part of consumers since many health problems are correlated to the consumption food products. Recently Al-Asmar et al. [22], concluded that the use of PEC as a dip coating material for the French fried provokes reduction ACR formation of about $48 \%$ in comparison to uncoated samples. Moreover, Suyatma et al. [23], have studied the synergistic effect of blanching and PEC coating of fried banana chips that resulted in high ACR reduction (up to $91.9 \%$ ).

The objective of this study was to evaluate the effect of both TGase and PEC-based coating solution on the ACR formation and quality of the fried falafel. Oil and water content, texture analysis profile, and in vitro gastric digestion were investigated. Results demonstrated the effectiveness of our coatings providing healthier falafel.

\section{Materials and Methods}

\subsection{Materials}

ACR standard $299.8 \%$, and methanol were supplied from the Sigma-Aldrich Chemical Company (St. Louis, MO, USA). Acetonitrile HPLC analytical grade, n-hexane, and formic acid were obtained from Carlo Erba reagents S.r.l. (Cornaredo, MI, Italy). Oasis HLB 200 mg, 6 mL solid phase extraction (SPE) cartridges were from Waters (Milford, MA, USA). Syringe filters $(0.45$ and $0.22 \mu \mathrm{m}$ PVDF) were from Alltech Associates (Deerfield, Italy). PEC of Citrus peel low-methylated (7\%) (Aglupectin USP) was purchased from Silva Extracts s.r.l. (Gorle, BG Italy) and ACTIVA WM Streptoverticillium TGase was supplied by Ajinomoto Co. (Tokyo, Japan). All the other reagents were of analytical grade. Corn oil and chickpea were purchased from a local super market. 


\subsection{Preparation of PEC Coating Solutions}

PEC-based solutions $(1 \% w / v)$ were prepared according to Al-Asmar et al. [22] and Esposito et al. [24], from a PEC stock solution $(2 \% w / v)$, then diluted with water and the $\mathrm{pH}$ was adjusted to 7.5 . Finally, the solution was stirred for $30 \mathrm{~min}$ at $25^{\circ} \mathrm{C}$.

\subsection{Falafel Preparation and Dipping Process}

\subsubsection{Falafel Dough}

The dough was made of a mixture of soaked chickpeas, onion, parsley, falafel spices, salt and sodium bicarbonate. The mixture was blended for $2 \mathrm{~min}$ by water. Then the falafel balls were formed by using a special scoop, and fried as described below.

\subsubsection{Falafel Dough Treated with TGase}

After prepared the falafel dough as described above, TGase (5 and $20 \mathrm{U} / \mathrm{g}$ protein) was added to the dough after incubation at $37^{\circ} \mathrm{C}$ for $2 \mathrm{~h}$, the falafel balls were formed and fried. The control falafel samples were obtained without TGase but treated under the same conditions.

\subsubsection{PEC Dipping}

The falafel dough treated or not with TGase was frozen at $-20{ }^{\circ} \mathrm{C}$ for $2 \mathrm{~h}$, then dipped in $1 \%$ PEC. The control was dipped in water, then frozen again for $30 \mathrm{~min}$ then fried.

\subsection{Frying Process}

Falafel balls were fried at $180 \pm 5^{\circ} \mathrm{C}$ for $5 \mathrm{~min}$, by using $2 \mathrm{~L}$ of corn oil, using a deep-fryer apparatus (GIRMI, Viterbo, Italy) [22,25]. The oil was replaced with fresh one for each group. Each fried group were flipping from side to side every $2 \mathrm{~min}$. After frying, each sample was allowed to drain for 2 min to remove the excess oil [22].

\subsection{Sodium Dodecyl Sulphate Polyacrylamide Gel Electrophoresis (SDS-PAGE)}

For SDS-PAGE of falafel balls, an aliquot of $250 \mu \mathrm{L}$ of sample buffer $(15 \mathrm{mM}$ of Tris- $\mathrm{HCl}, \mathrm{pH}$ 6.8, containing $0.5 \%(w / v)$ of SDS, $2.5 \%(v / v)$ of glycerol, $200 \mathrm{mM}$ of $\beta$-mercaptoethanol, and $0.003 \%$ $(w / v)$ of bromophenol blue) was added to $25 \mathrm{mg}$ of falafel dough and/or fried falafel (either untreated or treated with TGase) and analyzed by $12 \%$ SDS-PAGE. The samples were heated at $100{ }^{\circ} \mathrm{C}$ for $5 \mathrm{~min}$, and then centrifuged for $10 \mathrm{~min}$ at $13,000 \times \mathrm{g} .10 \mu \mathrm{L}$ of each supernatant were analyzed by SDS-PAGE (12\%). SDS-PAGE was performed as described by Laemmli [26], at constant voltage (80 V for 2-3 h), and the proteins were stained with Coomassie Brilliant Blue R250 (Bio-Rad, Segrate, Milan, Italy). Bio-Rad Precision Protein Standards were used as molecular weight markers.

\subsection{In Vitro Gastric Digestion}

Fried falafel balls either treated or not by ( $20 \mathrm{U} / \mathrm{g}$ protein) TGase were subjected to in vitro digestion by using adult model $[12,27,28]$, under gastric physiological conditions. For our analyses, $100 \mathrm{mg}$ of each sample were incubated with $4 \mathrm{~mL}$ of Simulated Salivary Fluid (SSF, $150 \mathrm{mM}$ of $\mathrm{NaCl}, 3 \mathrm{mM}$ of urea, $\mathrm{pH} 6.9$ ) containing $75 \mathrm{U}$ of amylase enzyme/g protein for $5 \mathrm{~min}$ at $37{ }^{\circ} \mathrm{C}$ and $170 \mathrm{rpm}$. The amylase activity was blocked by adjusting the $\mathrm{pH}$ at 2.5 . Afterwards the samples were subjected to gastric digestion as described by Giosafatto et al. [12] with some modifications. Briefly, $100 \mu \mathrm{L}$ of Simulated Gastric Fluid (SGF, $0.15 \mathrm{M}$ of $\mathrm{NaCl}, \mathrm{pH} 2.5$ ) were placed in $1.5 \mathrm{~mL}$ microcentrifuge tubes and added to $100 \mu \mathrm{L}$ of oral phase then incubated at $37^{\circ} \mathrm{C}$. Therefor, $50 \mu \mathrm{L}$ of pepsin $(0.1 \mathrm{mg} / \mathrm{mL}$ dissolved in SGF) were added to start the digestion reaction. At intervals of 1,2 , $5,10,20,40,60 \mathrm{~min}, 40 \mu \mathrm{L}$ of $0.5 \mathrm{M}$ of ammonium bicarbonate $\left(\mathrm{NH}_{4} \mathrm{HCO}_{3}\right)$ were added to each vial to stop the pepsin reaction. The control was set up by incubating the sample for $60 \mathrm{~min}$ without the protease. The samples were then analyzed using the SDS-PAGE (12\%) procedure described above. 


\subsection{ACR Standard Preparation}

The standard stock solution $(1.0 \mathrm{mg} / \mathrm{mL})$ was prepared as described by Al-Asmar et al. [22]. Then it was diluted at different concentrations (100, 250, 500, 1000, 2000, 3000, 4000, 5000 and $10000 \mu \mathrm{g} / \mathrm{L}$ ), respectively. All series of standard solutions were stored in glass dark bottles (lightresistant) at $4{ }^{\circ} \mathrm{C}$ until used.

\subsection{Extraction of ACR from the Falafel Balls}

ACR extraction from fried falafel balls was carried out according to Al-Asmar et al. [22], with some modifications. About $160 \mathrm{~g}$ of fried falafel balls, after cooling, were immersed in hexane for $30 \mathrm{~min}$ to remove the oil from their surfaces [29]. The falafel balls were then grinded by using a rotary mill (Grindomix GM200, Retsch GmbH, Haan, Germany) at speed of $1300 \mathrm{rpm}$ for $1 \mathrm{~min}$. Each sample was allowed to dry by freeze-drying before being subjected to ACR extraction following the protocols reported by Wang et al. [30] and Krishna et al. [31]. Two different falcon tubes were set up for each sample, one for detecting ACR formed in the sample itself, and the second one to carry out the recovery test. In both tubes $1 \mathrm{~g}$ of grinded sample was put and only in the second one $100 \mu \mathrm{g} / \mathrm{L}$ of ACR standard were added. $50 \mu \mathrm{L}$ of Carrez reagent potassium salt and $50 \mu \mathrm{L}$ of Carrez reagent zinc salts were added to each sample. In each tube $10 \mathrm{~mL}$ of HPLC water were added. The samples were extracted in an incubated shaker for $30 \mathrm{~min}$ at $25^{\circ} \mathrm{C}$ and $170 \mathrm{rpm}$, then followed by centrifugation at $8000 \mathrm{rpm}$ for $10 \mathrm{~min}$ at $4{ }^{\circ} \mathrm{C}$. The supernatant was filtered through a $0.45 \mu \mathrm{m}$ syringe filter for Oasis HLB SPE cartridges clean-up. The SPE cartridge was conditioned with $2 \mathrm{~mL}$ of methanol followed by $2 \mathrm{~mL}$ of HPLC water before loading $3 \mathrm{~mL}$ of filtered supernatant, the first $0.5 \mathrm{~mL}$ were discarded and the remaining elute were collected $(\approx 1.5 \mathrm{~mL})$. The all different extracts were kept in dark glass vials at $4{ }^{\circ} \mathrm{C}$ before analysis. The clean sample extracts were further filtered through $0.2 \mu \mathrm{m}$ nylon syringe filters, and analyzed by TOF LC-MS. Each analysis was performed in triplicate.

\subsection{LC-MS Analysis for ACR Content of Fried Falafel}

The determination of ACR concentration was performed using the Agilent 6230 TOF-LC/MS coupled to series HPLC system, a vacuum degasser, binary pumps, and a temperature-controlled column oven at $30{ }^{\circ} \mathrm{C}$. The following MS parameters were used: positive ion mode, nebulizer pressure $35 \mathrm{psi}$, drying gas $\left(\mathrm{N}_{2}\right) 5 \mathrm{~L} / \mathrm{min}$ and $325^{\circ} \mathrm{C}$, capillary voltage $3500 \mathrm{~V}$ and fragmentor $175 \mathrm{~V}$.

The column used was a Synergi ${ }^{\mathrm{TM}} 4 \mu \mathrm{m}$ Hydro-RP $80 \AA$ A HPLC Column $250 \times 3$ mm [22,32] (from Phenomenex, Torrance, CA, USA). The operating conditions were as follows: the mobile phase was a gradient elution: mixture water/acetonitrile $(97 / 3, v / v)$ containing $0.10 \%(v / v)$ formic acid Solvent A and Solvent B was acetonitrile containing $0.10 \%(v / v)$ formic acid. The program elution was applied as follows: $100 \%$ A $(0 \%$ B) for 8 min, increased to $80 \%$ B (20\% A) from 8 to $15 \mathrm{~min}$, and kept at $80 \% \mathrm{~B}(20 \% \mathrm{~A})$ for $10 \mathrm{~min}$, increased to $100 \% \mathrm{~A}(0 \% \mathrm{~B})$ from 25 to $30 \mathrm{~min}$, and kept at $100 \%$ A for $5 \mathrm{~min}$, at flow rate $0.4 \mathrm{~mL} / \mathrm{min}$. The injection volume was $20 \mu \mathrm{L}$. The total chromatographic runtime was $35 \mathrm{~min}$ for each sample; ACR elutes at retention time $3 \mathrm{~min}$, then the peak identification was based on the Extracted Ion Chromatogram (EIC); by selecting ion at $m / z 72$, calibration curves were obtained by plotting the peak area of ACR versus concentration of ACR (range of concentration: $0.05-10 \mathrm{mg} / \mathrm{L}$ ). The equation was obtained by applying the linear regression was $y=102.21 x-10.706$, with a $R^{2}$ equal to 0.9991 ; this equation was used to calculate the amount of ACR in all analyzed samples.

\subsection{Oil Content}

The oil content of each fried falafel balls were grinned into pieces of $(3-5 \mathrm{~g})$. The oil content was measured gravimetrically in triplicate, by using Soxhlet method [33], and reported as a percentage on dry matter weight. 


\subsection{Water Content Analysis}

Water content of each fried falafel ball samples were measured gravimetrically in triplicate, according to AOAC [34].

\subsection{Texture Profile Analysis (TPA)}

Texture profile analysis of falafel balls for each sample was carried out as described by Rossi Marquez et al. [25] with some modifications. In particular, each falafel balls sample was analyzed using an Instron universal testing instrument model No. 5543A (Instron Engineering Corp., Norwood, MA, USA) equipped with a $2 \mathrm{kN}$ load cell in compression mode with a cylindrical probe (55 $\mathrm{mm}$ in diameter). The instrumental TPA described by Bourne [35], was used. The test was configured so that the three TPA parameters, hardness, chewiness and gumminess, were calculated at the time of the test by determining the load and displacement at predetermined points on the TPA curve. Pre- and post-test speeds were $2.0 \mathrm{~mm} / \mathrm{s}$, while test speed was $1.0 \mathrm{~mm} / \mathrm{s}$. Samples, prepared as described above, were centered and compressed to $30 \%$ of deformation. Hardness $(\mathrm{N})$ was derived from the positive peak obtained at the first compression of the product or a maximum exhibited compression force. Chewiness $(\mathrm{N} \mathrm{mm})$ was the mathematical product by the software Bluehill (version 2.21) from the hardness, cohesiveness, and springiness [36]. Gumminess (N) was calculated by the software Bluehill automatically by multiply the hardness with the cohesiveness that is a ratio of the positive force areas under first and second compressions. All the TPA analyses were carried out with at least eight balls per each treatment.

\subsection{Statistical Analysis}

All the experiments were performed three times, and the data were analyzed by using the JMP version 10.0 software (SAS Institute, Cary, NC, USA). Statistical differences were considered using the Tukey-Kramer HSD test to be significant at $(p<0.05)$.

\section{Results and Discussion}

\subsection{Modification of the Protein Component of Falafel Balls by Means of TGase}

Adding different concentrations ( 0,5 and $20 \mathrm{U}$ TGase/g chickpea protein) to the falafel dough and mixed very well, after incubation for $\left(2 \mathrm{~h}\right.$ at $\left.37^{\circ} \mathrm{C}\right)$ we analyzed the SDS-PAGE $(12 \%)$, for the dough and also for the falafel after frying. The $\mathrm{pH}$ value of the falafel dough was 7 , treatment that does not contain TGase was the control for this experiment. Figure 1, demonstrated that TGase (5 and $20 \mathrm{U} / \mathrm{g}$ protein) were able, under these experimental conditions, to modify chickpea proteins and this modification does not change during frying. The results indicated that chickpea proteins in a good substrate for the TGase. Moreover, the large polymers were clear demonstrated by increasing the TGase concentration to $(20 \mathrm{U} / \mathrm{g}$ protein) and disappearance of protein bands with a lower molecular mass (Figure 1, Panels A and B). 


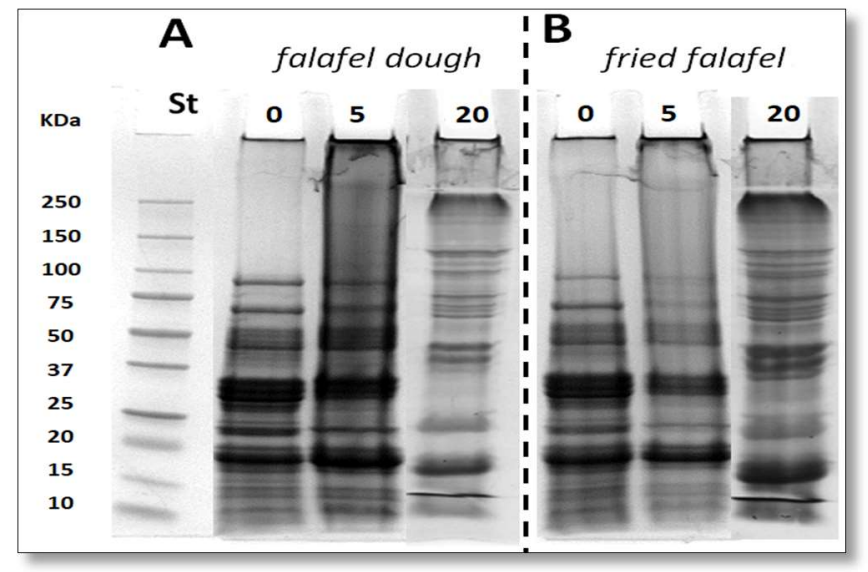

Figure 1. Panel A: SDS-PAGE of falafel dough without TGase (lane 1), with $5 \mathrm{U} / \mathrm{g}$ TGase-treated (lane 2) and 20 U/g TGase-treated (lane 3); Panel B: SDS-PAGE of fried falafel without TGase (lane 1), with $5 \mathrm{U} / \mathrm{g}$ TGase-treated (lane 2) and $20 \mathrm{U} / \mathrm{g}$ TGase-treated (lane 3); St, Molecular weight standards, Bio-Rad. (Panel A) falafel dough; (Panel B) fried falafel.

\subsection{Effect of TGase and/or 1\% PEC Coating Solution on the ACR Content of Falafel Balls}

According to EFSA scientists report, ACR is an health concern, ACR is formed during frying, baking or roasting starchy rich food and also in the food contain higher protein concentration and sulfhydryl groups [37,38]. Traditional fried falafel balls were analyzed for their ACR content, which was equal to $7229 \mu \mathrm{g} / \mathrm{kg}$. Whereas, the falafel prepared by adding 5 or $20 \mathrm{U}$ TGase $/ \mathrm{g}$ protein, demonstrated a significant reduction of the ACR concentration, $10.8 \%$ and $34.4 \%$ respectively (Figure 2, Panel A). This reduction could be explained by two different ways: (i) by the ability of TGase to crosslink the lysine and glutamine providing a network that could retain free amino acids involved into ACR formation; (ii) the higher water content of the falafel balls prepared in the presence of TGase compared to the water content in falafel prepared in the absence of the enzyme (Figure 3). In fact, in our previous paper Al-Asmar et al. [22] we have demonstrated that, in French fries, higher moisture content was lowering ACR content.

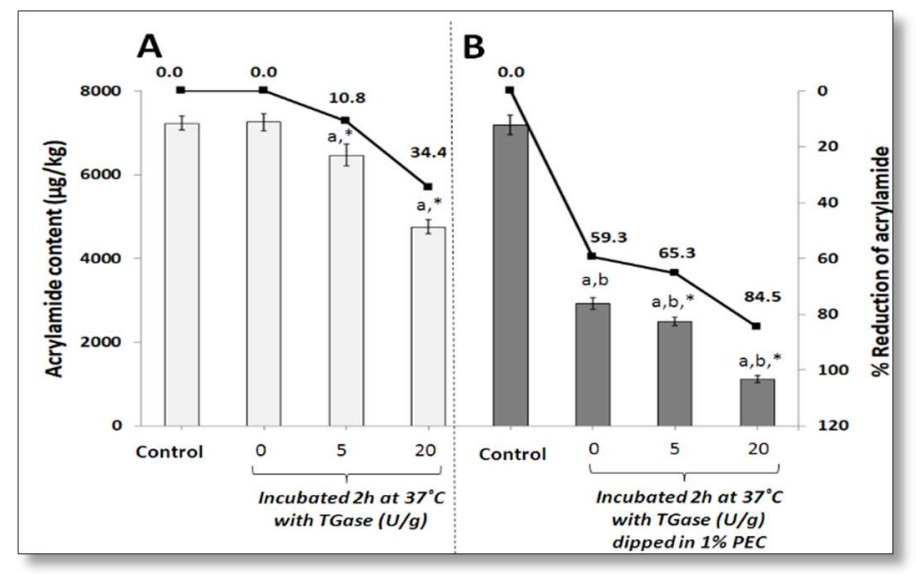

Figure 2. Effect of different concentrations of TGase on ACR content of fried falafel prepared without dipping (Panel A) or with dipping into 1\% PEC-based coating solution (Panel B). The ACR content was determinated on fat-free dry matters and reported as percentage of ACR reduction of fried falafel balls. The columns significantly different from those obtained by analyzing the control are indicated by " $a$ ", the columns indicated by " $b$ " were significantly different from those obtained without dipping, whereas the columns indicated by "** were significantly different from those prepared with different TGase concentrations (Tukey means comparison, $p<0.05$ ). Control of Panel A represents ACR content in fried traditional falafel. Control of Panel B represents ACR content in fried falafel dipped in water. 


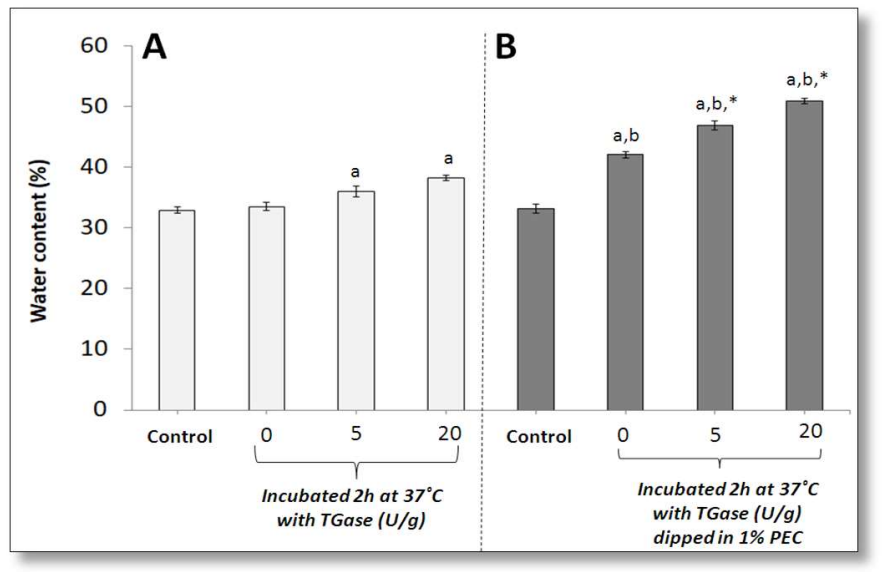

Figure 3. Effect of different concentrations of TGase on water content of fried falafel balls prepared without dipping (Panel A) or with dipping into 1\% PEC coating solution (Panel B).The columns significantly different from those obtained by analyzing the untreated are indicated by " $a$ ", the columns indicated by " $b$ " were significantly different from those obtained without dipping, whereas the columns indicated by "** were significantly different from those prepared with different TGase concentrations (Tukey means comparison, $p<0.05$ ). Control of Panel A represents ACR content in fried traditional falafel. Control of Panel B represents ACR content in fried falafel dipped in water.

To study the effect of coating, the ACR content was also determined in the falafel dipped in both water and 1\% PEC-based solutions. The results, shown in Figure 2, Panel B, indicate that the ACR content was $40.7 \%$, in comparison to the ACR content of falafel dipped in water or not dipped. As it is shown in both Panels A and B of Figure 2, falafel balls prepared by TGase followed by dipping into 1\% PEC-based solution showed a significant reduction in ACR content in comparison to the uncoated falafel. The lowest amount of ACR $(1118 \mu \mathrm{g} / \mathrm{kg})$ was exhibited by falafel balls prepared by $20 \mathrm{U} / \mathrm{g}$ TGase and coated with 1\% PEC-based solutions, where the percentage of the ACR reduction was $84.5 \%$. In addition, the recovery test was performed to assess the extraction efficiency for each sample; to this aim the ACR content before and after the addition of $100 \mu \mathrm{g} / \mathrm{L}$ of ACR standard was determined. Percentage recovery was determined according to the following formula [22].

$$
\operatorname{Recovery}(\%)=\frac{\text { ACR }(\text { detected after standard addition })-\text { ACR }(\text { sample })}{\text { ACR }(\text { standard added })} \times 100
$$

The results of recovery studies are showed in Table 1 . The recovery values were in the range of $89 \%-102 \%$, that are statistically in line with experimental deviations.

Table 1. Recovery test for ACR in all falafel types (in each sample $100 \mu \mathrm{g} \backslash \mathrm{L}$ of ACR standard were added).

\begin{tabular}{|c|c|c|}
\hline Falafel Type & $\begin{array}{l}\text { ACR Content in Spiked Sample } \\
(\mu \mathrm{g} / \mathrm{kg})\end{array}$ & Recovery (\%) \\
\hline Traditional falafel & $7329 \pm 188$ & 100 \\
\hline Incubated $2 \mathrm{~h}$ at $37^{\circ} \mathrm{C}$ without TGase & $7349 \pm 140$ & 94.2 \\
\hline Incubated $2 \mathrm{~h}$ at $37^{\circ} \mathrm{C}$ with TGase $5 \mathrm{U} / \mathrm{g}$ & $6560 \pm 147$ & 92.6 \\
\hline Incubated $2 \mathrm{~h}$ at $37^{\circ} \mathrm{C}$ with TGase $20 \mathrm{U} / \mathrm{g}$ & $4852 \pm 217$ & 96.8 \\
\hline Dipped in water & $7294 \pm 348$ & 102 \\
\hline $\begin{array}{c}\text { Incubated } 2 \mathrm{~h} \text { at } 37^{\circ} \mathrm{C} \text { without TGase and dipped in } \\
1 \% \text { PEC }\end{array}$ & $3017 \pm 115$ & 90.7 \\
\hline $\begin{array}{c}\text { Incubated } 2 \mathrm{~h} \text { at } 37^{\circ} \mathrm{C} \text { with TGase }(5 \mathrm{U} / \mathrm{g}) \text { and } \\
\text { dipped in } 1 \% \text { PEC }\end{array}$ & $2583 \pm 65$ & 89.3 \\
\hline $\begin{array}{c}\text { Incubated } 2 \mathrm{~h} \text { at } 37^{\circ} \mathrm{C} \text { with TGase }(20 \mathrm{U} / \mathrm{g}) \text { and } \\
\text { dipped in } 1 \% \text { PEC }\end{array}$ & $1219 \pm 83$ & 101 \\
\hline
\end{tabular}




\subsection{Effect of TGase and/or 1\% PEC Coatings on Water and Oil Content of Falafel Balls}

Analyzing the water content of fried falafel, indicated that the falafel prepared in the presence of TGase ( 5 or $20 \mathrm{U} / \mathrm{g}$ protein) contains more water in comparison to the falafel prepared without TGase or to the control (Figure 3, Panel A). Moreover, dipping the falafel into 1\% PEC-based solution increasing the water content significantly compared to the control (Figure 3, Panel B).

Treating falafel with TGase and PEC-based solution increased the water content significantly compared to both controls. The TGase concentration (20 U/g protein) together with dipping into $1 \%$ PEC-based solution retained the highest water value. The obtained results could be explained by the TGase-mediated crosslinking that is responsible of water evaporation reduction during frying $[22,25]$.

The oil content of the falafel balls is the main problem of such fast food products that contain about $25 \%$ oil, based on the dry weight. The oil is responsible for several health problems such as cardiovascular disease, overweight, and obesity [39]. Treated the falafels with (5 or $20 \mathrm{U} / \mathrm{g}$ protein) TGase does not show any reduction on the oil content (Figure 4, Panel A). However, the presence of PEC -based solution significantly reduces the oil content to about 23\%. Many authors [25,40,41], have reported that PEC leads to a lower oil uptake. For example, in the previous paper Al-Asmar et al. [22] we have demonstrated that PEC-based coating reduces oil uptake in French fries. To our knowledge, few studies have been devoted to decrease oil absorption in fried falafel balls. Pinthus et al. [42] and Mansour. [43], have investigated the influence of added powdered cellulose and methyl cellulose or fibers or hydrocolloids, and have demonstrated their ability to reduce the oil uptake during falafel ball deep frying.

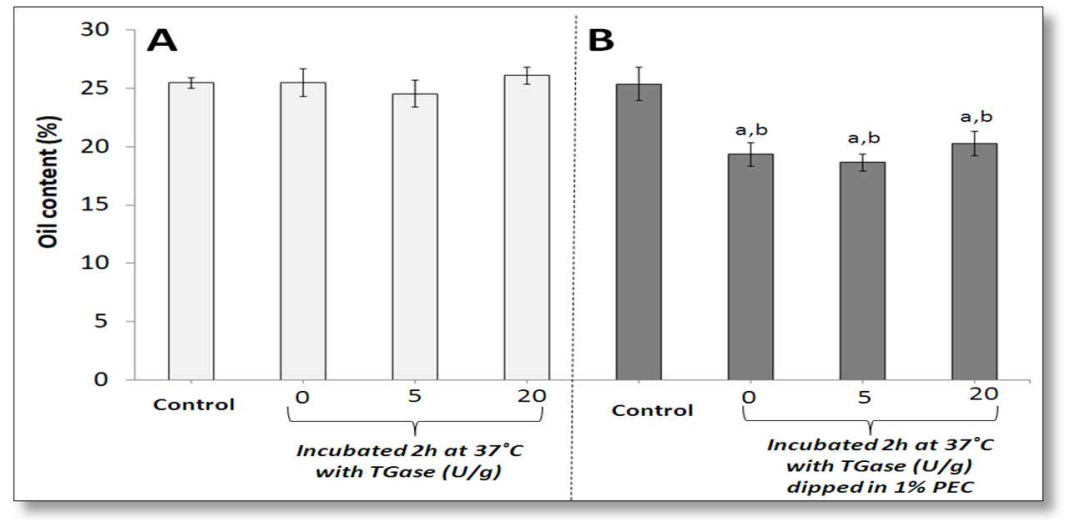

Figure 4. Effect of different concentrations of TGase without dipping (Panel A) or with dipping into $1 \%$ PEC coating solution (Panel B), on oil content prepared based on dry matters of fried falafel balls. The columns significantly different from those obtained by analyzing the untreated are indicated by " $a$ ", whereas the columns indicated by " $b$ " were significantly different from those obtained without dipping (Tukey means comparison, $p<0.05$ ). Control of Panel A represents ACR content in fried traditional falafel. Control of Panel B represents ACR content in fried falafel dipped in water.

\subsection{Effect of TGase and/or 1\% PEC Coatings on Texture Profile Analysis (TPA)}

To verify whether or not enzyme treatment and coating could influence the quality of falafel balls, texture profile analysis (TPA) was performed. Thus, falafel hardness, chewiness, and gumminess were assessed. As shown in Table 2, falafel balls prepared with TGase showed an increasing on all three parameters. Moreover, TGase-treated falafel balls coated with 1\% PEC-based solution showed as well significantly higher hardness, chewiness and gumminess values compared to the sample incubated in the absence of the enzyme and dipped into PEC-based solution. 
Table 2. Texture Profile Analysis (TPA) of falafel balls prepared in the presence or absence of different concentrations of TGase dipped or not into 1\% PEC solution prepared at pH 7.5.

\begin{tabular}{|c|c|c|c|}
\hline Falafel Type & Hardness (N) & $\begin{array}{c}\text { Chewiness } \\
\text { (N mm) }\end{array}$ & Gumminess (N) \\
\hline Traditional falafel & $56.41 \pm 5.50$ & $184.28 \pm 3.10$ & $23.20 \pm 1.20$ \\
\hline Incubated $2 \mathrm{~h}$ at $37^{\circ} \mathrm{C}$ without TGase & $52.22 \pm 5.30$ & $180.97 \pm 2.80$ & $22.15 \pm 1.20$ \\
\hline Incubated $2 \mathrm{~h}$ at $37^{\circ} \mathrm{C}$ with TGase $5 \mathrm{U} / \mathrm{g}$ & $70.88 \pm 3.25$ a & $238.44 \pm 2.70$ a & $38.87 \pm 1.50$ a \\
\hline Incubated $2 \mathrm{~h}$ at $37^{\circ} \mathrm{C}$ with TGase $20 \mathrm{U} / \mathrm{g}$ & $96.57 \pm 4.80$ a & $280.25 \pm 15.10$ a & $49.64 \pm 3.80$ a \\
\hline Dipped in water & $52.18 \pm 3.40$ & $178.13 \pm 4.10$ & $21.42 \pm 3.01$ \\
\hline Incubated $2 \mathrm{~h}$ at $37^{\circ} \mathrm{C}$ without TGase and dipped in $1 \%$ PEC & $58.13 \pm 4.90$ & $183.23 \pm 11.69$ & $23.29 \pm 4.50$ \\
\hline Incubated $2 \mathrm{~h}$ at $37^{\circ} \mathrm{C}$ with TGase $(5 \mathrm{U} / \mathrm{g}$ ) and dipped in $1 \%$ PEC & $114.31 \pm 8.20$ a,b & $453.18 \pm 11.30 \mathrm{a}, \mathrm{b}$ & $67.60 \pm 4.50 \mathrm{a}, \mathrm{b}$ \\
\hline Incubated $2 \mathrm{~h}$ at $37^{\circ} \mathrm{C}$ with TGase $(20 \mathrm{U} / \mathrm{g})$ and dipped in $1 \%$ PEC & $136.07 \pm 12.28 \mathrm{a}, \mathrm{b}$ & $518.50 \pm 18.05 \mathrm{a}, \mathrm{b}$ & $78.24 \pm 2.01 \mathrm{a}, \mathrm{b}$ \\
\hline
\end{tabular}

Notes: The results significantly different from those obtained by analyzing the untreated are indicated by "a", whereas the results indicated by " $b$ " were significantly different from those obtained without dipping (Tukey means comparison, $p<0.05$ ).

\subsection{Effect of TGase on Digestibility of Falafel Balls}

To test the effect of enzyme-treatment on digestibility of falafel, an in vitro digestion (IVD) model was used. The protocol come from FA1005 (INFOGEST) [44], IVD experiments were carried out using falafel balls prepared in the presence and absences of $20 \mathrm{U}$ TGase/g. At the end of the simulated gastric digestion, samples were analyzed by SDS-PAGE. A it is possible to see in Figure 5, the sample " $C$ " exhibits proteins fully precipitated, not matter if they were incubated or not with TGase (see Figure 5, lane " $C$ ", of both Panels A and B), such samples were treated with simulated gastric fluid (SGF) that did not contain pepsin. This result is likely due to the gelation and aggregation of the food sample during the heat treatment [45]. In the other hand, as expected, when samples were treated with SGF containing pepsin, the protein component present in falafel was gradually digested. TGase slightly decreased the protein digestibility rate of the falafel balls, even though, at the end of digestion in both systems, they were completely hydrolyzed by the gastric enzyme pepsin (Figure 5). These results were also supported by the densitometry analysis (Figure 6) of the protein bands having a molecular mass between 35 and $25 \mathrm{kDa}$, (Figure 5, Panel A, samples prepared without TGase), and the high molecular mass polymers of $250 \mathrm{kDa}$ (Figure 5 panel B, falafel balls prepared by the means of TGase). As shown in Figure 6 the digestion rate is slower in the food incubated with the TGase enzyme, even though at the end of the digestion, the proteins analyzed are fully digested by pepsin in both untreated and TGase treated falafel.

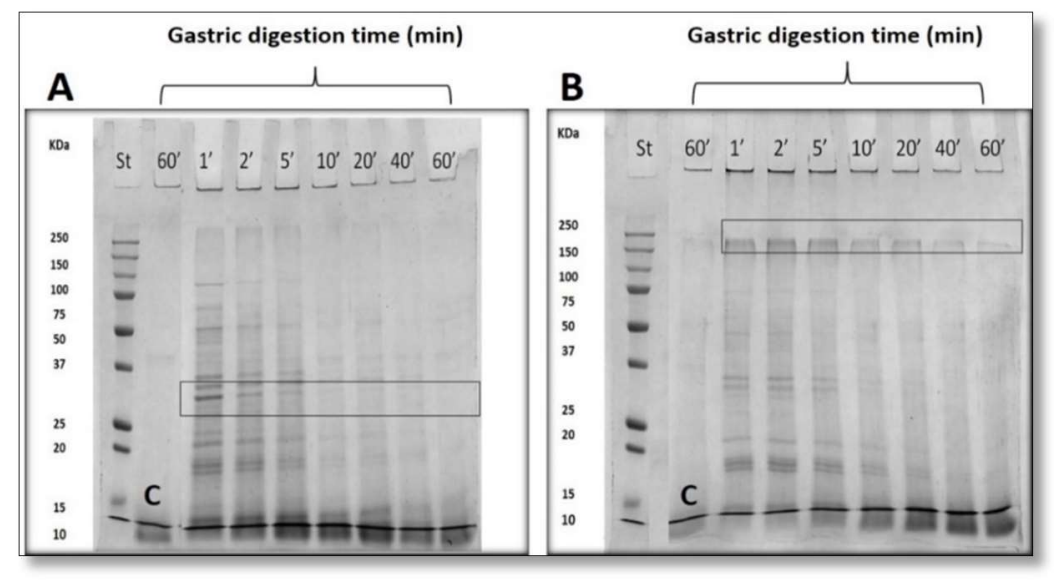

Figure 5. SDS-PAGE profile of falafel subjected to in vitro experiments. Panel A: traditional falafel prepared in the absence of TGase. Panel B: falafel prepared in the presence of TGase $(20 \mathrm{U} / \mathrm{g})$. The bands in the frame are those subjected to densitometry analysis. $\mathrm{C}$ is control sample incubated with simulated gastric solution not containing pepsin. St, Molecular weight standards, Bio-Rad. 


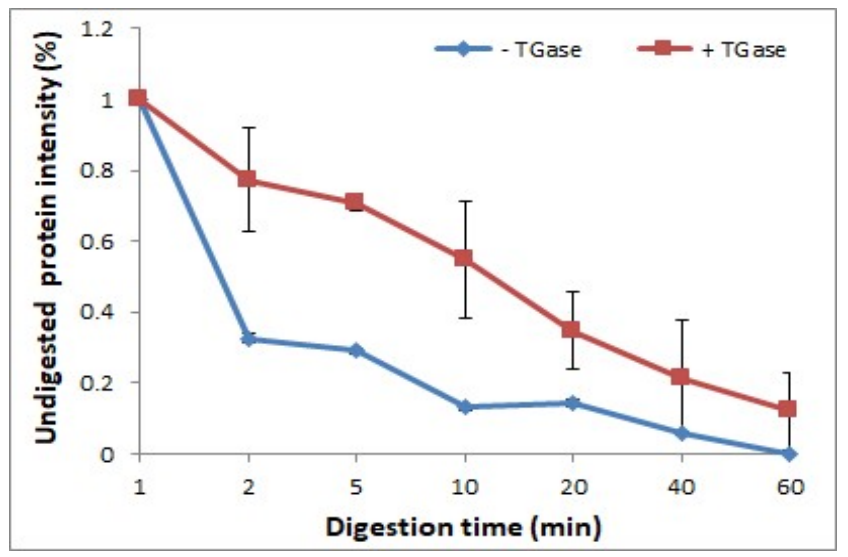

Figure 6. Densitometry analysis of the SDS-PACE bands relative to in vitro digestion shown in Figure 5. Both falafel types, traditional and $(20 \mathrm{U} / \mathrm{g})$ TGase-containing samples, were subjected to densitometry analysis.

\section{Conclusions}

In this paper for the first time falafel balls, a typical Middle Eastern food, were produced by using in their dough TGase. After the preparation of the balls, they were treated by dipping them in a PEC-based coating. We demonstrated that the use of the enzyme provoked the reduction of the ACR in falafel balls, which was even more evident when TGase-prepared balls were coated by PEC, that was able to decrease the ACR concentration also in the falafel prepared without TGase. However, TGase also had an effect on the texture profile parameters. On the other hand, the PEC coating protection allowed to reduce the oil content of this food product, either treated or not by means of TGase. In addition, protein gastric digestion, carried out under physiological conditions, showed that enzymatic treatment slightly decreased the digestion rate, although the proteins were fully digested at the end of the experiment in both unprocessed and TGase-processed systems.

Author contributions: L.M. supervised and conceived the project; L.M. and A.A. designed the experiments; A.A. performed the experiments; A.A., C.V.L.G., and L.P. analyzed the data; L.M. and A.A. co-wrote the paper; C.V.L.G. and L.M. reviewed and re-edited the paper; all authors discussed the results and commented on the manuscript.

Acknowledgements: The authors would like to acknowledge Maria Fenderico for technical support.

Conflicts of interest: The authors declare that they do not have any conflicts of interests.

\section{References}

1. Abdullah, T. Reduction of oil uptake in deep fat fried falafel. J. Nutr. Health Food Eng. 2015, 2, 00059. doi:10.15406/jnhfe.2015.02.00059.

2. Abu-Alruz, K. Effect of frying time and falafel ball size on fat uptake during deep fat frying. J. Agric. Environ. Sci. 2015, 15, 1648-1654.

3. Jodi, K. A history of the mideast in the humblechickpea. The New York Times, July 2002.

4. Al-Dmoor, H.M.; Humeid, M.A.; Alawi, M.A. Investigation of acrylamide levels in selected fried and baked foods in Jordan. Food Agr. Environ. 2004, 2, 157-165.

5. United States department of agriculture agricultural, research service national nutrient database for standard reference legacy release. Available online: https://ndb.nal.usda.gov/ndb/foods/show?ndbno=16138\&fg=\&man=\&lfacet=\&format=Abridged\&count= $\& \max =25 \&$ offset $=5675 \&$ sort $=\mathrm{c} \& q$ lookup $=\& \mathrm{rptfrm}=\mathrm{nl} \&$ nutrient $1=415 \&$ nutrient $2=\&$ nutrient $3=\&$ subset $=0 \& \mathrm{t}$ otCount=7669\&measureby=m. (accessed on 1 February 2019).

6. Tareke, E.; Rydberg, P.; Karlsson, P.; Eriksson, S.; Törnqvist, M. Analysis of acrylamide, a carcinogen formed in heated foodstuffs. J. Agric. Food Chem. 2002, 50, 4998-5006.

7. Mottram, D.S.; Wedzicha, B.L.; Dodson, A.T. Food chemistry: Acrylamide is formed in the Maillard reaction. Nature 2002, 419, 448-449. 
8. EFSA CONTAM Panel (EFSA Panel on Contaminants in the Food Chain). Scientific opinion on acrylamide in food. EFSA J. 2015, 13, 4104. doi:10.2903/j.efsa.2015.4104.

9. Sabbah, M.; Giosafatto, C.V.L.; Esposito, M.; Di Pierro, P.; Mariniello, L.; Porta, R. Transglutaminase cross-linked edible films and coatings for food applications. In Enzymes in Food Biotechnology, 1st ed.; Kuddus, M., Ed.; Academic Press: New York, NY, USA, 2019; pp. 369-388.

10. Giosafatto, C.V.L.; Al-Asmar, A.; Mariniello, L. Transglutaminase protein substrates of food interest. In Enzymes in Food Technology: Improvement and Innovation; Kuddus, M., Eds.; Springer Nature Singapore Private Limited: Singapore, 2018; pp. 293-317.

11. Pakseresht, S.; Mazaheri Tehrani, M.; Razavi, S.M.A. Optimization of low-fat set-type yoghurt: effect of altered whey protein to casein ratio, fat content and microbial transglutaminase on rheological and sensorial properties. J. Food Sci. Technol. 2017, 54, 2351-2360.

12. Giosafatto, C.V.L.; Rigby, N.M.; Wellner, N.; Ridout, M.; Husband, F.; Mackie, A.R. Microbial transglutaminase-mediated modification of ovalbumin. Food Hydrocolloid. 2012, 26, 261-267.

13. Huang, T.; Tu, Z.; Wang, H.; Shangguan, X.; Zhang, L.; Zhang, N.; Bansal, N. Pectin and enzyme complex modified fish scales gelatin: Rheological behavior, gel properties and nanostructure. Carbohyd. Polym. 2017, 156, 294-302.

14. Mariniello, L.; Di Pierro, P.; Esposito, C.; Sorrentino, A.; Masi, P.; Porta, R. Preparation and mechanical properties of edible pectin-soy flour films obtained in the absence or presence of transglutaminase. J. Biotechnol. 2003, 102, 191-198

15. Xing, G.; Giosafatto, C.V.L.; Rui, X.; Dong, M.; Mariniello, L. Microbial transglutaminase-mediated polymerization in the presence of lactic acid bacteria affects antigenicity of soy protein component present in bio-tofu. J. Funct. Foods 2019, 53, 292-298.

16. Porta, R.; Di Pierro, P.; Sabbah, M.; Regalado-Gonzales, C.; Mariniello, L.; Kadivar, M.; Arabestani, A. Blend films of pectin and bitter vetch (Vicia ervilia) proteins: Properties and effect of transglutaminase. Innov. Food Sci. Emerg. Technol. 2016, 36, 245-251.

17. Giosafatto, C.V.L.; Al-Asmar, A.; D'Angelo, A.; Roviello, V.; Esposito, M.; Mariniello, L. Preparation and characterization of bioplastics from grass pea flour cast in the presence of microbial transglutaminase. Coatings 2018, 8, 435.

18. Lara-Espinoza, C.; Carvajal-Millán, E.; Balandrán-Quintana, R.; López-Franco, Y.; Rascón-Chu, A. Pectin and pectin-based composite materials: beyond food texture. Molecules 2018, 23, 942.

19. Padmaja, N.; John, D.S. Preservation of sapota (Manilkara zapota) by edible aloe vera gel coating to maintain its quality. Int. J. Sci. Res. 2014, 3, 177-179.

20. Valdés, A.; Burgos, N.; Jiménez, A.; Garrigós, M.C. Natural pectin polysaccharides as edible coatings. Coatings 2015, 5, 865-886.

21. Yossef M.A. Comparison of different edible coatings materials for improvement of quality and shelf life of perishable fruits. Middle East J. Appl. Sci. 2014, 4, 416-424.

22. Al-Asmar, A.; Naviglio, D.; Giosafatto, C.V.L.; Mariniello, L. Hydrocolloid-based coatings are effective at reducing acrylamide and oil content of French fries. Coatings 2018, 8, 147.

23. Suyatma, N.E.; Ulfah, K.; Prangdimurti, E.; Ishikawa, Y. Effect of blanching and pectin coating as prefrying treatments to reduce acrylamide formation in banana chips. Int. Food Res. J. 2015, 22, 936-942.

24. Esposito, M.; Di Pierro, P.; Regalado-Gonzales, C.; Mariniello, L.; Giosafatto, C.V.L.; Porta, R. Polyamines as new cationic plasticizers for pectin-based edible films. Carbohydr. Polym. 2016, 153, 222-228.

25. Rossi Marquez, G.; Di Pierro, P.; Esposito, M.; Mariniello, L.; Porta, R. Application of transglutaminasecrosslinked whey protein/pectin films as water barrier coatings in fried and baked foods. Food Bioprocess Technol. 2013, 7, 447-455.

26. Laemmli, U.K. Cleavage of structural proteins during the assembly of the head of Bacteriophage T4. Nature 1970, 227, 680-985.

27. Bourlieu, C.; Ménard, O.; Bouzerzour, K.; Mandalari, G.; Macierzanka, A.; Mackie, A.R.; Dupont, D. Specificity of infant digestive conditions: Some clues for developing relevant in vitro models. Crit. Rev. Food Sci. Nutr. 2014, 54, 1427-1457.

28. Minekus, M.; Alminger, M.; Alvito, P.; Balance, S.; Bohn, T.; Bourlieu, C.; Carrière, F.; Boutrou, R.; Corredig, M.; Dupont, D.; et al. A standardised static in vitro digestion method suitable for food-An international consensus. Food Funct. 2014, 5, 1113-1124. 
29. Zeng, X.; Cheng, K.-W.; Du, Y.; Kong, R.; Lo, C.; Chu, I.K.; Chen, F.; Wang, M. Activities of hydrocolloids as inhibitors of acrylamide formation in model systems and fried potato strips. Food Chem. 2010, 121, 424428.

30. Wang, H.; Feng, F.; Guo, Y.; Shuang, S.; Choi, M.M.F. HPLC-UV quantitative analysis of acrylamide in baked and deep-fried Chinese foods. J. Food Compos. Anal. 2013, 31, 7-11.

31. Krishna, V.N.; Meyyanathan, S.N.; Karthik, Y.; Hemnath, E.; Satiesh, K.R.; Usha K. A simple and validated RP HPLC method for the estimation of acrylamide in potato chips. World J. Pharm. Pharm. Sci. 2014, 3, 1468-1476.

32. Michalak, J.; Gujska, E.; Kuncewicz, A. RP-HPLC-DAD studies on acrylamide in cereal-based baby foods. J. Food Compos. Anal. 2013, 32, 68-73.

33. Association of Official Analytical Chemists. Method 960.39. In Official Methods of Analysis, 15th ed.; Helrich, K., Ed.; AOAC International: Arlington, VA, USA, 1990.

34. Association of Official Analytical Chemists. Method 950.46. In Official Methods of Analysis, 15th ed.; Helrich, K., Ed.; AOAC International: Arlington, VA, USA, 1990.

35. Bourne, M.-C. Texture profile analysis. Food Technol. 1978, 32, 62-66,72

36. Meullenet, J.-F.; Lyon, B.-G.; Carpenter, J.-A.; Lyon, C.-E. Relationship between sensory and instrumental texture profile attributes. J. Sens. Stud. 1998, 13, 77-93.

37. Salazar, R.; Arámbula-Villa, G.; Hidalgo, F.J.; Zamora, R. Mitigating effect of piquin pepper (Capsicum annuum L. var. Aviculare) oleoresin on acrylamide formation in potato and tortilla chips. LWT-Food Sci. Technol. 2012, 48, 261-267.

38. Salazar, R.; Arámbula-Villa, G.; Vázquez-Landaverde, P.A.; Hidalgo, F.J.; Zamora, R. Mitigating effect of amaranth (Amarantus hypochondriacus) protein on acrylamide formation in foods. Food Chem. 2012, 135, 2293-2298.

39. Sayon-Orea, C.; Bes-Rastrollo, M.; Basterra-Gortari, F.J.; Beunza, J.J.; Guallar-Castillon, P.; de la FuenteArrillaga, C.; Martinez-Gonzalez, M.A. Consumption of fried foods and weight gain in a mediterranean cohort: The sun project. Nutr. Metab. Cardiovasc. Dis. 2013, 23, 144-150.

40. Daraei Garmakhany, A.; Mirzaei, H.O.; Maghsudlo, Y.; Kashaninejad, M.; Jafari, S.M. Production of low fat French-fries with single and multilayer hydrocolloid coatings. J. Food Sci. Technol. 2014, 51, 1334-1341.

41. Mahajan, I.; Sonka, C.; Surendar, J. Study on the effective reduction of oil up-take by the application of edible hydrocolloid coatings on French fries. Int. J. Eng. Sci. Adv. Technol. 2014, 2. Available online: http://www.ijreat.org/Papers\%202014/Issue9/IJREATV2I3056.pdf (accessed on 1 February 2019)

42. Pinthus, E.J.; Weinberg, P.; Saguy, I.S. Criterion for oil uptake during deep-fat frying. J. Food Sci. 1993, 58, 204-206.

43. Mansour, E.H. Quality of deep-fat frying Falafel balls as influenced by various fibers and hydrocolloids. Minufiya J. Agric. Res. 2003, 28, 491-502.

44. FA-1005-Improving health properties of food by sharing our knowledge on the digestive process (INFOGEST). Available online: https://www.cost.eu/actions/FA1005/\#tabs I Name:overview (accessed on 1 February 2019).

45. Opazo-Navarrete, M.; Altenburg, M.D.; Boom, R.M.; Janssen, A.E.M. The effect of gel microstructure on simulated gastric digestion of protein gels. Food Biophysics. 2018, 13, 124-138.

(C) 2019 by the authors. Licensee MDPI, Basel, Switzerland. This article is an open access article distributed under the terms and conditions of the Creative Commons Attribution (CC BY) license (http://creativecommons.org/licenses/by/4.0/). 